\title{
Association of an INSIG2 obesity allele with cardiovascular phenotypes is gender and age dependent
}

\author{
Kimberly A Skelding ${ }^{1 *}$, Glenn S Gerhard ${ }^{1}$, Helen Vlachos², Faith Selzer ${ }^{2}$, Sheryl F Kelsey², Xin Chu', Robert Erdman', \\ David O Williams ${ }^{3}$, Kevin E Kip ${ }^{4}$
}

\begin{abstract}
Background: The INSIG2 gene has been implicated in cholesterol metabolism and a single nucleotide polymorphism (SNP) near INSIG2 has been shown to be associated with obesity. We sought to determine the relationship of the INSIG2 SNP to cardiovascular disease (CVD) related phenotypes.

Methods and Results: Nine hundred forty six patients undergoing percutaneous coronary intervention $(\mathrm{PCl})$ in wave 5 of the multicenter NHLBI Dynamic Registry were genotyped using RT-PCR/TaqMan/allelic discrimination for the rs7566605 SNP near the INSIG2 gene. Clinical variables analyzed include demographics, medical history, and procedural details. The prevalence of peripheral vascular disease (PVD) was significantly higher in older men ( $\geq 65$ years) who were either homozygous or carriers of the obesity/lipid risk allele (" $\mathrm{C}$ ") compared to non-carriers (odds ratio 3.4, $p=0.013$ ) using a logistic regression model incorporating history of hypercholesterolemia, history of hypertension, cerebrovascular disease, history of diabetes, and BMI. A similar relationship with cerebrovascular disease was found in older ( $>65)$ women (odds ratio 3.4, $p=0.013$ ). The INSIG2 SNP was not associated with BMI, nor with other clinical variables.
\end{abstract}

Conclusion: Age and gender may influence the association of the INSIG2 obesity SNP with PVD and cerebrovascular disease in patients with pre-existing CVD.

\section{Background}

Risk factors for atherosclerosis related disorders include dyslipidemia and obesity. The insulin signaling protein type 2 gene (INSIG2) has been shown to be involved in lipid and cholesterol metabolism in vitro and in animal studies [1-3], and has been linked to obesity in humans through genetic studies. For example, INSIG2 interacts with transcription factors that activate the synthesis of cholesterol and fatty acids in the liver and other organs [4]. In addition, a common single nucleotide polymorphism (SNP rs7566605) near the INSIG2 gene was found to be associated with BMI in a genome-wide association study from the Framingham Heart Study offspring cohort [5]. Playing both a key role in cholesterol homeostasis and as a genetic susceptibility factor for

\footnotetext{
* Correspondence: kaskelding@geisinger.edu

'Weis Center for Research, Geisinger Medical Center, 100 North Academy Avenue, Danville, PA 17822, USA

Full list of author information is available at the end of the article
}

obesity makes it an attractive candidate locus for lipidrelated phenotypes such as cardiovascular disease, as well as for BMI.

The initial association of BMI with homozygosity for the minor allele of the INSIG2 rs7566605 SNP was followed by both negative and positive associations involving analysis of many thousands of individuals [6-9]. Studies in severe obesity have also failed to associate the SNP with blood lipid parameters [10,11], although medication use (e.g., statins) was not accounted for. However, in populations with lower BMI levels, a gender effect may be present $[12,13]$. Little or no association has been found with coronary artery disease in population-based studies [10,14-16], nor with obesity in cohorts recruited for cardiovascular phenotypes [6]. The goal of this study was to determine the relationship between the INSIG2 rs7566605 SNP and multiple cardiovascular phenotypes in a well-characterized population of patients with known coronary artery disease. 


\section{Methods}

\section{Population}

The National Heart Lung and Blood Institute-sponsored Dynamic Registry was utilized for this study. In brief, the multi-center Dynamic Registry was designed to characterize changes in clinical practice, particularly evolving technology, on short- and long-term patient outcomes. Five recruitment waves of approximately 2000 patients each have been enrolled and followed over the past 10 years to examine trends in PCI. Each center received approval from its institutional review board. No control patients not undergoing PCI were included in the study.

This analysis was restricted to Wave 5 patients recruited from February 2006 to August 2006 who consented to the genomic sub-study. Of the 15 Wave 5 clinical centers, 11 participated in the collection of blood samples. The study population consisted of 947 patients, $70.6 \%$ of whom were male with a median age 64 years and a median BMI of $29.0 \mathrm{~kg} / \mathrm{m}^{2}$, in whom at least one stent had been placed with a yearly post-procedure follow-up scheduled to 5 years. The racial/ethnic distribution was 77.7\% Caucasian, 14.0\% African American, $1.1 \%$ Asian, and 7.0\% Hispanic. Approximately $35.3 \%$ of patients never smoked, $24.1 \%$ were current smokers at the time of enrollment, and $40.6 \%$ were former smokers. A history of hypertension was found in $78.2 \%$, hypercholesterolemia in $79.4 \%$, a prior myocardial infarction in $24.8 \%$, cerebrovascular disease in $7.0 \%$, renal disease in $9.9 \%$, peripheral vascular disease (PVD) in $7.5 \%$, pulmonary disease in $8.1 \%$, cancer in $8.5 \%$, and diabetes in $37.4 \%$.

Of the 947 patients in Wave 5 consented for the genomics sub study, 821 (86.7\%) received only drug-eluting stents, 48 (5.1\%) received bare-metal stents only, 39 (4.1\%) received both a drug-eluting stent and a bare-metal stent and $39(4.1 \%)$ received balloon angioplasty alone.

\section{Data}

Data collected included baseline demographic, clinical, and angiographic characteristics and procedural details during the index PCI, as well as the occurrence of death, myocardial infarction, and the need for coronary-artery bypass grafting (CABG) during hospitalization. A blood draw for genomic analysis was added to Wave 5 and was obtained in dually consented patients $(n=947)$. Followup status was ascertained at 1 month, 6 months, and annually thereafter. The follow-up rate at 1 year was $97 \%$. With the use of the Social Security Administration's Death Master File (http://www.ntis.gov/products/ssadmf.aspx), coordinators periodically evaluated the vital status of patients who were lost to follow-up. For patients who underwent subsequent repeat revascularization (either PCI or CABG), vessel-specific and lesion-specific data were collected whenever possible to determine the occurrence of target-vessel revascularization.

\section{DNA isolation}

DNA was extracted from $0.35 \mathrm{ml}$ of EDTA anti-coagulated whole blood using the Qiagen MagAttract DNA Blood Midi M48 Kit and Qiagen BioRobot M48 Workstation (Qiagen, Valencia, CA) according the manufacturer's directions. The final elution volume was $200 \mathrm{ul}$. Quantification of DNA extracted was performed using a NanoDrop ND-1000 spectrophotometer (NanoDrop Technologies, Wilmington, DE).

\section{Genotyping}

Single nucleotide polymorphism (SNPs) genotyping was performed on an Applied Biosystems 7500 real-time PCR System (Applied Biosystems, Foster City, CA)[17]. Assay reagents for each SNP were obtained from Applied Biosystems (INSIG2, rs7566605, assay ID: C_29404113_20). DNA was genotyped according to the manufacturer's protocol. Briefly, the reaction components for each genotyping reaction were as follows: 10 ng of DNA, $5 \mu \mathrm{L}$ of TaqMan Genotyping Master Mix (Applied Biosystems, Foster City, CA), $0.25 \mu \mathrm{L}$ of assay mix $(40 \times)$, and water up to a total volume of $10 \mu \mathrm{L}$. The thermocycler conditions were as follows: $50^{\circ} \mathrm{C}$ for $2 \mathrm{~min}$, $95^{\circ} \mathrm{C}$ for $10 \mathrm{~min}$, and 40 cycles of $95^{\circ} \mathrm{C}$ for $15 \mathrm{sec}$ and $60^{\circ}$ $\mathrm{C}$ for $60 \mathrm{sec}$. The reaction was then analyzed by Applied Biosystems Sequence Detection Software (version 2.01).

\section{Statistical analysis}

All statistical analyses were performed with the use of SAS software, version 9.1, and a two-sided P value of $\leq 0.05$ was considered to indicate statistical significance. Differences in baseline characteristics between the groups were detected using a Chi-Square test for the categorical variables and a T-test for the continuous variables when 2 groups are present. ANOVA was used for testing differences among 3 or more groups of continuous variables. One year cumulative event rates of clinical outcomes (MI, CABG, repeat PCI, Stent Thrombosis and composite outcomes (MI/CABG, CABG/rep PCI, MI/CABG/rep PCI) were estimated by the KaplanMeier method and tested by the log-rank statistic. Fisher's exact test was used to test INSIG2 genotypes for departure from Hardy-Weinberg equilibrium using the Helix Tree software package (Golden Helix, Bozeman, MT).

Four age and gender groups were analyzed using a stepwise logistic regression model to estimate the independent effects of different variables of interest, as well as the INSIG2 genotype. For men $>=65$ years of age, PVD was close to being significant. The odds ratio of the CC_GC genotype from the model was adjusted for 
history of hypercholesterolemia, history of hypertension, cerebrovascular disease, history of diabetes, and BMI. For men $<65$ years of age, history of hypercholesterolemia was close to being significant. A similar analysis was used to adjust the odds ratio of the CC_GC genotype. The additional variables in the model that were adjusted for were PVD, history of hypertension, cerebrovascular disease, history of diabetes, and BMI. For women $>=65$ years of age, cerebrovascular disease was close to being significant. The additional variables the model was adjusted for were: history of hypercholesterolemia, PVD, history of diabetes, and BMI. For women < 65 years of age, history of hypercholesterolemia was close to being significant. The additional variables the model was adjusted for were PVD, history of hypertension, history of cerebrovascular disease, history of diabetes, and BMI.

\section{Results}

DNA samples were genotyped for the INSIG2 (rs7566605) SNP variant. Genotyping consisted of analyzing the DNA from each patient to determine whether they carried the "G" and/or "C" DNA sequences near the INSIG2 gene. The INSIG2 "C" SNP is considered the 'obesity/lipid risk' allele. The frequency of the INSIG2 SNP in this population is shown in Table 1 and is in good agreement with previous studies [9]. The genotype distribution did not deviate from Hardy-Weinberg equilibrium $(\mathrm{p}=0.82)$. Because patients with African ancestry represent the largest single racial/ethnic subgroup (Table 2), we compared the allele frequency of our population with available data from the HapMap (http://www.hapmap.org). Very little difference in allele frequency was present among Caucasian and African populations.

The diploid INSIG2 SNP genotypes (i.e., "CC", "GC", and "GG") were also analyzed (Table 2). The INSIG2 homozygous "CC" genotype was present in $\sim 10 \%$ of the population. The INSIG2 heterozygous "GC" genotype was present at $43.6 \%$ and the INSIG2 low obesity risk "GG" was present in $46.5 \%$. Genotype breakdown by ethnic/racial sub-group is also presented.

We then determined whether the frequencies of the more than 30 clinical parameters (Table 3) related to coronary artery disease and stent placement were

Table 1 Frequencies of the INSIG2 SNP alleles

\begin{tabular}{llllllll}
\hline Population & allele & freq & count & allele & freq & count & Total \\
\hline Caucasian & C & 0.331 & 515 & G & 0.669 & 1041 & 1556 \\
AA & C & 0.243 & 66 & G & 0.757 & 206 & 272 \\
Utah & C & 0.265 & 60 & G & 0.735 & 166 & 226 \\
Kenya & C & 0.275 & 78 & G & 0.725 & 206 & 284 \\
Nigeria & C & 0.230 & 52 & G & 0.770 & 174 & 226 \\
\hline
\end{tabular}

Table 2 Frequencies of INSIG2 genotypes

\begin{tabular}{llll}
\hline $\begin{array}{l}\text { Total } \\
\mathbf{( N =} \mathbf{9 4 7})\end{array}$ & $\mathbf{C C}$ & $\mathbf{G C}$ & $\mathbf{G G}$ \\
\hline White & $85(10.9 \%)$ & $345(44.3 \%)$ & $348(44.7 \%)$ \\
Black & $8(5.9 \%)$ & $50(36.8 \%)$ & $78(57.4 \%)$ \\
Asian & $0(0 \%)$ & $5(50 \%)$ & $5(50 \%)$ \\
Other & $1(4.3 \%)$ & $13(56.5 \%)$ & $9(39.2 \%)$ \\
\hline
\end{tabular}

different among patients with the three INSIG2 obesity/ lipid SNP genotypes. No differences, either before or after correcting for multiple comparisons, were present in BMI across genotype groups. No significant differences were present among the genotypes for gender, race/ethnicity, or smoking status. The percentage of patients undergoing a prior stent placement or CABG, as well as the percentage with a history of in-stent restenosis or the type of stent implanted was also not different among the genotypes. Although the percentages of patients with a history of prior MI and a history of cerebrovascular disease were different prior to Bonferroni correction, they did not reach significance after correction. No differences were seen for histories of diabetes, renal disease, chest pain, PVD, pulmonary disease, cancer, hypercholesterolemia, or hypertension.

Further inspection of the data revealed that the highest percentage of patients with a history of prior MI were the patients homozygous for the "CC" obesity/lipid risk allele. Similarly, patients who were either "CC" homozygotes or "GC" heterozygotes had the higher percentage of a history of cerebrovascular disease. There was also a trend for patients with a history of PVD to have the $\mathrm{C}$ allele. A dominant model was therefore used to analyze the data by comparing patients homozygous for the non-risk genotype ("GG") versus the patients carrying at least one obesity/lipid risk "C" allele ("GC" plus "CC"). Because of the strong influence of gender and age on coronary artery disease, the data were also re-analyzed by age and gender (Table 4 ). In men $\geq 65$ years of age, the percent with a history of PVD was almost three-fold higher in patients carrying one or two "C" alleles (Bonferroni adjusted $\mathrm{p}=0.05$ ). Conversely in women $\geq 65$ years of age, the percent with a history of cerebrovascular disease was also higher in patients carrying one or two " $\mathrm{C}$ " alleles, although this was close to, but did not reach, statistical significance after correcting for multiple comparisons. These data suggest a sexrelated effect of the INSIG2 obesity/lipid allele.

A stepwise logistic regression was then used to estimate the independent effects of different variables, as well as the INSIG2 genotype, on PVD in men $\geq 65$ years and cerebrovascular disease in women $\geq 65$ years, as well as history of hypercholesterolemia for both women and men $<65$ years of age. As shown in Table 5, the 
Table 3 Patient demographics, disease history, and INSIG2 genotypes

\begin{tabular}{|c|c|c|c|c|c|c|}
\hline Characteristic & $\begin{array}{l}\text { Total } \\
(\mathrm{N}=947)\end{array}$ & $\begin{array}{l}\mathrm{CC} \\
(\mathrm{N}=94)\end{array}$ & $\begin{array}{l}\mathrm{GC} \\
(\mathrm{N}=413)\end{array}$ & $\begin{array}{l}\mathrm{GG} \\
(\mathrm{N}=440)\end{array}$ & p_value & $\begin{array}{l}\text { Adjusted } \\
\text { p_value }\end{array}$ \\
\hline Age, mean, median & $64.0,64$ & $64.2,64$ & $65.1,65$ & $63.0,63$ & 0.0571 & 1.0000 \\
\hline Female, \% & 29.4 & 23.4 & 28.6 & 31.4 & 0.2748 & 1.0000 \\
\hline \multicolumn{7}{|l|}{ Race, \% } \\
\hline White & 77.7 & 87.2 & 80.8 & 72.7 & 0.0490 & 1.0000 \\
\hline Black & 14.0 & 8.5 & 11.4 & 17.5 & & \\
\hline Asian & 1.1 & 0.0 & 1.2 & 1.1 & & \\
\hline Hispanic & 7.0 & 4.3 & 6.1 & 8.4 & & \\
\hline Other & 0.3 & 0.0 & 0.5 & 0.2 & & \\
\hline Height $(\mathrm{cm})$, mean, median & $171.3,173$ & $172.9,173$ & $171.7,173$ & $170.6,171$ & 0.1450 & 1.0000 \\
\hline Weight $(\mathrm{kg})$, mean, median & $87.3,85$ & $89.1,87$ & $86.6,85$ & $87.5,85$ & 0.4407 & 1.0000 \\
\hline Body mass index $(\mathrm{kg} / \mathrm{m} 2)$, mean, median & $29.7,29$ & $29.6,29$ & $29.4,28$ & $30.1,29$ & 0.1616 & 1.0000 \\
\hline \multicolumn{7}{|l|}{ Smoking, \% } \\
\hline Never & 35.3 & 34.5 & 36.9 & 34.0 & 0.9078 & 1.0000 \\
\hline Current & 24.1 & 23.0 & 23.3 & 25.1 & & \\
\hline Former & 40.6 & 42.5 & 39.7 & 40.9 & & \\
\hline Patient previously treated with a stent, $\%$ & 32.4 & 37.2 & 30.1 & 33.5 & 0.3268 & 1.0000 \\
\hline History of in-stent restenosis, $\%$ & 23.3 & 26.5 & 22.6 & 23.1 & 0.8909 & 1.0000 \\
\hline \multicolumn{7}{|l|}{ Stent type } \\
\hline Coated, \% & 16.0 & 19.1 & 13.1 & 18.0 & 0.1020 & 1.0000 \\
\hline Uncoated, \% & 9.6 & 12.8 & 10.7 & 8.0 & 0.2266 & 1.0000 \\
\hline \multicolumn{7}{|l|}{ Prior CABG, \% } \\
\hline None & 81.4 & 79.8 & 80.3 & 82.6 & 0.8098 & 1.0000 \\
\hline One & 16.8 & 19.1 & 17.5 & 15.8 & & \\
\hline More than one & 1.8 & 1.1 & 2.2 & 1.6 & & \\
\hline Acute MI & 25.2 & 23.4 & 27.5 & 23.4 & 0.4472 & 1.0000 \\
\hline Prior MI, \% & 24.9 & 31.5 & 20.3 & 27.8 & 0.0131 & 0.2882 \\
\hline History Diabetes, \% & 37.4 & 29.8 & 38.0 & 38.5 & 0.2716 & 1.0000 \\
\hline History Cerebrovascular, \% & 7.0 & 5.3 & 9.9 & 4.8 & 0.0125 & 0.2875 \\
\hline History Renal Disease, \% & 9.9 & 9.6 & 9.9 & 10.0 & 0.9902 & 1.0000 \\
\hline History Chest Pain (angina), \% & 54.3 & 57.4 & 53.4 & 54.5 & 0.7716 & 1.0000 \\
\hline History PVD, \% & 7.5 & 11.7 & 8.4 & 5.7 & 0.0851 & 1.0000 \\
\hline History Pulmonary Disease, \% & 8.1 & 7.4 & 8.9 & 7.5 & 0.7500 & 1.0000 \\
\hline History Cancer, \% & 8.5 & 9.6 & 9.9 & 7.1 & 0.3235 & 1.0000 \\
\hline History Hypercholesterolemia, \% & 79.4 & 81.7 & 75.9 & 82.2 & 0.0707 & 1.0000 \\
\hline History Hypertension, \% & 78.2 & 81.7 & 78.5 & 77.0 & 0.5931 & 1.0000 \\
\hline
\end{tabular}

adjusted odds ratio for a history of PVD in older men who carried at least one INSIG2 obesity/lipid allele increased to 3.4 $(\mathrm{p}=0.013)$. Similarly the adjusted odds ratio for a history of cerebrovascular disease in older women increased to $5.5(\mathrm{p}=0.04)$. The association with genotype in the models was not significant for history of hypercholesterolemia.

\section{Discussion and Conclusions}

Cardiovascular disease is associated with a number of risk factors such as smoking, hypercholesterolemia, hypertension, type 2 diabetes, and abdominal obesity. Genetic variations may influence susceptibility to these risk factors, as well as direct susceptibility to CAD or
MI $[18,19]$. Obesity is a multi-factorial process that is associated with an increased risk of cardiovascular disease, suggesting that they may share common determinants. An ideal candidate for such a shared predisposition is the INSIG2 gene, which may influence susceptibility through effects on cholesterol metabolism and/or obesity.

Previous studies have failed to find a significant association between the INSIG2 rs7566605 SNP and history of CAD/MI $[10,14,15]$. We cannot determine whether this is also the case for our population, which consisted of patients with existing coronary artery disease because a weakness of the study design is the lack of a control population without CAD. Given these limitations, no 
Table 4 Association of INSIG2 obesity allele and cardiovascular phenotypes by gender and age

\begin{tabular}{|c|c|c|c|c|c|}
\hline \multirow[b]{2}{*}{ Characteristic } & \multicolumn{4}{|c|}{ Men, Age $\geq 65$} & \multirow[b]{2}{*}{ Adjusted p-value } \\
\hline & $\begin{array}{c}\text { Total } \\
(\mathrm{N}=290)\end{array}$ & $\begin{array}{c}C C \& G C \\
(N=171)\end{array}$ & $\begin{array}{c}\text { GG } \\
(\mathrm{N}=119)\end{array}$ & p_value & \\
\hline Body mass index $(\mathrm{kg} / \mathrm{m} 2)$, mean, median & $27.7,27$ & $27.8,27$ & $27.6,27$ & 0.92 & 1.0000 \\
\hline History Hypercholesterolemia, \% & 82.6 & 82.2 & 83.2 & 0.83 & 1.0000 \\
\hline Prior MI, \% & 28.7 & 25.7 & 33.0 & 0.18 & 0.7200 \\
\hline Cerebrovascular, \% & 12.2 & 14.2 & 9.3 & 0.21 & 0.7200 \\
\hline \multirow[t]{3}{*}{ PVD, \% } & 10.5 & 14.2 & 5.1 & 0.01 & 0.0500 \\
\hline & \multicolumn{4}{|c|}{ Men, Age $<65$} & \\
\hline & Total & CC \& GC & GG & & Adjusted $p$-value \\
\hline Characteristic & $(\mathrm{N}=377)$ & $(\mathrm{N}=195)$ & $(\mathrm{N}=182)$ & p_value & \\
\hline Body mass index $(\mathrm{kg} / \mathrm{m} 2)$, mean, median & $30.5,30$ & $30.2,30$ & $30.8,30$ & 0.30 & 0.9000 \\
\hline History Hypercholesterolemia, \% & 77.5 & 74.6 & 80.6 & 0.17 & 0.8500 \\
\hline Prior MI, \% & 25.4 & 22.7 & 28.3 & 0.21 & 0.8500 \\
\hline Cerebrovascular, \% & 3.5 & 4.1 & 2.7 & 0.46 & 0.9000 \\
\hline \multirow[t]{2}{*}{ PVD, \% } & 5.6 & 6.7 & 4.4 & 0.33 & 0.9000 \\
\hline & \multicolumn{4}{|c|}{ Women, Age $\geq 65$} & \\
\hline \multirow[t]{2}{*}{ Characteristic } & Total & CC \& GC & GG & p_value & Adjusted $p$-value \\
\hline & $(N=151)$ & $(N=79)$ & $(N=72)$ & & \\
\hline Body mass index $(\mathrm{kg} / \mathrm{m} 2)$, mean, median & $29.6,29$ & $29.5,29$ & $29.7,29$ & 0.83 & 1.0000 \\
\hline History Hypercholesterolemia, \% & 81.1 & 78.9 & 83.3 & 0.50 & 1.0000 \\
\hline Prior Ml, \% & 22.7 & 20.5 & 25.0 & 0.53 & 1.0000 \\
\hline Cerebrovascular, \% & 8.0 & 12.8 & 2.8 & 0.02 & 0.1000 \\
\hline \multirow[t]{2}{*}{ PVD, \% } & 8.0 & 7.7 & 8.3 & 0.88 & 1.0000 \\
\hline & \multicolumn{4}{|c|}{ Women, Age $<65$} & \\
\hline \multirow[t]{2}{*}{ Characteristic } & Total & CC \& GC & GG & p_value & Adjusted p-value \\
\hline & $(\mathrm{N}=127)$ & $(N=61)$ & $(N=66)$ & & \\
\hline Body mass index $(\mathrm{kg} / \mathrm{m} 2)$, mean, median & $32.3,31$ & $31.5,30$ & $33.1,32$ & 0.2105 & 0.8420 \\
\hline History Hypercholesterolemia, \% & 75.6 & 67.2 & 83.1 & 0.0412 & 0.2060 \\
\hline Prior Ml, \% & 16.5 & 12.3 & 20.3 & 0.2351 & 0.8420 \\
\hline Cerebrovascular, \% & 4.8 & 5.2 & 4.5 & 0.8710 & 0.8710 \\
\hline PVD, \% & 5.6 & 3.4 & 7.6 & 0.3204 & 0.8420 \\
\hline
\end{tabular}

association was found with $\mathrm{CAD} / \mathrm{MI}$ severity related phenotypes including acute MI, history of prior MI, chest pain, and prior CABG. No association of rs7566605 was found with the cardiovascular risk factors hypertension, type 2 diabetes, obesity, or smoking.
The relationship of the INSIG2 obesity/lipid risk allele ("C") with hyperlipidemia appears to be complex. The rs7566605 SNP has been associated with a lower prevalence of hypercholesterolemia in a study of 885 Japanese Americans (347 men and 538 women) and 378 Japanese

Table 5 Logistic regression risk models for PVD, cerebrovascular disease, and hypercholesterolemia

\begin{tabular}{|c|c|c|c|c|}
\hline $\begin{array}{l}\text { Characteristic } \\
\text { (age and gender group) }\end{array}$ & $\begin{array}{l}\text { Adjusted Odds } \\
\text { Ratio } \\
\text { (CC \& GC/GG) }\end{array}$ & $\begin{array}{l}95 \% \\
\text { C.I. }\end{array}$ & $\begin{array}{c}P- \\
\text { value }\end{array}$ & Variables used in model \\
\hline $\begin{array}{l}\text { PVD } \\
\text { (men, age }>=65 \text { ) }\end{array}$ & 3.4 & $1.3,8.8$ & 0.013 & $\begin{array}{l}\text { History of hypercholesterolemia, history of hypertension, cerebrovascular disease, } \\
\text { history of diabetes, BMI }\end{array}$ \\
\hline $\begin{array}{l}\text { History of } \\
\text { Hypercholesterolemia } \\
\text { (men, age < 65) }\end{array}$ & 0.7 & $0.4,1.2$ & 0.23 & PVD, history of hypertension, cerebrovascular disease, history of diabetes, BMI \\
\hline $\begin{array}{l}\text { Cerebrovascular disease } \\
\text { (women, age }>=65 \text { ) }\end{array}$ & 5.5 & $\begin{array}{l}1.1 \\
27.7\end{array}$ & 0.04 & History of hypercholesterolemia, PVD, history of diabetes, BMI \\
\hline $\begin{array}{l}\text { History of } \\
\text { Hypercholesterolemia } \\
\text { (women, age < 65) }\end{array}$ & 0.4 & $0.2,1.0$ & 0.07 & PVD, history of hypertension, cerebrovascular disease, history of diabetes, BMI \\
\hline
\end{tabular}


individuals (182 men and 196 women), in which the rate of hypercholesterolemia was lower in Japanese American women homozygous for the obesity risk allele (GG, 62.2\%; GC, $57.1 \%$; CC, $42.1 \%$ ), but not in the other subjects [13]. No significant differences in BMI, waist circumference, or percentage body fat were found in either population. In contrast, in a study of 2,364 Koreans, the rs7566605 SNP was found to be associated with total cholesterol levels in a dominant model in females, although this association did not meet statistical significance after performing a Bonferroni correction [12]. Again, no association was found with BMI. Our initial analysis found a lower percentage of female patients with a history of hypercholesterolemia who carried at least one copy of the INSIG2 obesity/lipid risk allele ("C") that was not significant after correcting multiple comparisons. However, we did not have access to actual cholesterol measurements, thus patients with any degree of hypercholesterolemia were included in the same case group. Confounding effects of lipid-lowering medication use may also be important. Future studies addressing these factors will be needed to fully assess the relationship of the INSIG2 SNP and cholesterol levels.

We also did not find association with BMI. However, in animal models, the effect of the INSIG2 gene on body weight was seen with a low cholesterol diet [4]. Diet composition was not reported or available for our study or for most studies on BMI.

Our data indicate that the INSIG2 obesity/lipid risk allele ("C") was associated with a higher rate of PAD in older men and an even higher rate of cerebrovascular disease in older women, suggesting significant age and gender related effects. Several other variants have also been related to PAD $[20,21]$, with one sequence variant on chromosome 9p21 also associated with a variety of atherosclerotic phenotypes [17,19,22,23]. Relatively few data is available on the genetic predisposition to CVD $[23,24]$. PAD and CVD are both due to an atherosclerotic process, yet it is likely that specific molecular differences result in clinical disease in either the peripheral or cerebral vasculature. Larger studies on specific cohorts of patients with PVD and cerebrovascular disease will be needed to replicate our findings for INSIG2.

How the specific SNP sequences in the INSIG2 gene alter the function of the INSIG2 RNA and/or protein to increase the risk for PAD and CVD is not known. The INSIG2 SNP is located about 10,000 bases upstream from the coding region, so is likely to be involved in regulating the level of RNA and therefore the amount of protein produced. Future studies will be required to determine the molecular mechanism by which the specific INSIG2 DNA variants affect gene function.

\section{Acknowledgements}

a.) This research was supported by funds from the Geisinger Clinic and by the National Heart, Lung, and Blood Institute grants HL-33292-14 through HL-33292-22. b.) The authors thank Dr. Xin Chu for technical assistance and the participants in the Dynamic Registry.

\section{Author details}

${ }^{1}$ Weis Center for Research, Geisinger Medical Center, 100 North Academy Avenue, Danville, PA 17822, USA. ²Department of Epidemiology, University of Pittsburgh, PUBHL Pittsburgh, Pittsburgh, PA 15260, USA. ${ }^{3}$ Division of Cardiology, Brigham and Women's Hospital, 75 Francis St, Boston, MA 02115, USA. ${ }^{4}$ USF College of Nursing Research Center, University of South Florida, 4202 E. Fowler Avenue Tampa, FL 33620, USA.

\section{Authors' contributions}

RE and XC carried out the genotyping. HV, FS, and SFK performed the statistical analysis. DOW and KEK participated in its design and coordination. KAS and GSG conceived of the study, participated in its design and coordination, and drafted the manuscript. All authors read and approved the final manuscript.

\section{Competing interests}

The authors declare that they have no competing interests.

Received: 11 February 2010 Accepted: 29 September 2010 Published: 29 September 2010

\section{References}

1. Gong $Y$, Lee JN, Brown MS, Goldstein $J L$, Ye J: Juxtamembranous aspartic acid in Insig-1 and Insig-2 is required for cholesterol homeostasis. Proc Natl Acad Sci USA 2006, 103:6154-6159.

2. Yabe D, Brown MS, Goldstein JL: Insig-2, a second endoplasmic reticulum protein that binds SCAP and blocks export of sterol regulatory elementbinding proteins. Proc Natl Acad Sci USA 2002, 99:12753-12758.

3. Takaishi K, Duplomb L, Wang MY, Li J, Unger RH: Hepatic insig-1 or -2 overexpression reduces lipogenesis in obese Zucker diabetic fatty rats and in fasted/refed normal rats. Proc Natl Acad Sci USA 2004, 101:7106-7111.

4. Engelking LJ, Liang G, Hammer RE, Takaishi K, Kuriyama H, Evers BM, Li WP, Horton JD, Goldstein JL, Brown MS: Schoenheimer effect explainedfeedback regulation of cholesterol synthesis in mice mediated by Insig proteins. J Clin Invest 2005, 115:2489-2498.

5. Herbert A, Gerry NP, McQueen MB, Heid IM, Pfeufer A, Illig T, Wichmann HE, Meitinger T, Hunter D, Hu FB, Colditz G, Hinney A, Hebebrand J, Koberwitz K, Zhu X, Cooper R, Ardlie K, Lyon H, Hirschhorn JN, Laird NM, Lenburg ME, Lange C, Christman MF: A common genetic variant is associated with adult and childhood obesity. Science 2006, 312:279-283.

6. Bressler J, Fornage M, Hanis CL, Kao WH, Lewis CE, McPherson R, Dent R, Mosley TH, Pennacchio LA, Boerwinkle E: The INSIG2 rs7566605 genetic variant does not play a major role in obesity in a sample of 24,722 individuals from four cohorts. BMC Med Genet 2009, 10:56.

7. Kumar J, Sunkishala RR, Karthikeyan G, Sengupta S: The common genetic variant upstream of INSIG2 gene is not associated with obesity in Indian population. Clin Genet 2007, 71:415-418.

8. Smith AJ, Cooper JA, Li LK, Humphries SE: INSIG2 gene polymorphism is not associated with obesity in Caucasian, Afro-Caribbean and Indian subjects. Int J Obes (Lond) 2007, 31:1753-1755.

9. Lyon HN, Emilsson V, Hinney A, Heid IM, Lasky-Su J, Zhu X, Thorleifsson G, Gunnarsdottir S, Walters GB, Thorsteinsdottir U, Kong A, Gulcher J, Nguyen TT, Scherag A, Pfeufer A, Meitinger T, Bronner G, Rief W, SotoQuiros ME, Avila L, Klanderman B, Raby BA, Silverman EK, Weiss ST, Laird N, Ding X, Groop L, Tuomi T, Isomaa B, Bengtsson K, Butler JL, Cooper RS, Fox CS, O'Donnell CJ, Vollmert C, Celedon JC, Wichmann HE, Hebebrand J, Stefansson K, Lange C, Hirschhorn JN: The association of a SNP upstream of INSIG2 with body mass index is reproduced in several but not all cohorts. PLoS Genet 2007, 3:e61.

10. Boes E, Kollerits B, Heid IM, Hunt SC, Pichler M, Paulweber B, Coassin S, Adams TD, Hopkins PN, Lingenhel A, Wagner SA, Kronenberg F: INSIG2 polymorphism is neither associated with BMI nor with phenotypes of lipoprotein metabolism. Obesity (Silver Spring) 2008, 16:827-833. 
11. Chu X, Erdman R, Susek M, Gerst H, Derr K, Al-Agha M, Wood GC, Hartman C, Yeager S, Blosky MA, Krum W, Stewart WF, Carey D, Benotti P, Still CD, Gerhard GS: Association of morbid obesity with FTO and INSIG2 allelic variants. Arch Surg 2008, 143:235-240, discussion 241.

12. Cha S, Koo I, Choi SM, Park BL, Kim KS, Kim JR, Shin HD, Kim JY: Association analyses of the INSIG2 polymorphism in the obesity and cholesterol levels of Korean populations. BMC Med Genet 2009, 10:96.

13. Oki K, Yamane K, Kamei N, Asao T, Awaya T, Kohno N: The single nucleotide polymorphism upstream of insulin-induced gene 2 (INSIG2) is associated with the prevalence of hypercholesterolaemia, but not with obesity, in Japanese American women. Br J Nutr 2009, 101:322-327.

14. Liu X, Li Y, Lu X, Wang L, Zhao Q, Yang W, Huang J, Cao J, Li H, Gu D: Interactions among genetic variants from SREBP2 activating-related pathway on risk of coronary heart disease in Chinese Han population. Atherosclerosis 2009.

15. Liu X, Li Y, Wang L, Zhao Q, Lu X, Huang J, Fan Z, Gu D: The INSIG1 gene, not the INSIG2 gene, associated with coronary heart disease: tagSNPs and haplotype-based association study. The Beijing Atherosclerosis Study. Thromb Haemost 2008, 100:886-892.

16. Wiedmann S, Neureuther K, Stark K, Reinhard W, Kallmunzer B, Baessler A, Fischer M, Linsel-Nitschke P, Erdmann J, Schunkert H, Hengstenberg C: Lack of association between a common polymorphism near the INSIG2 gene and BMI, myocardial infarction, and cardiovascular risk factors. Obesity (Silver Spring) 2009, 17:1390-1395.

17. Wood GC, Still CD, Chu X, Susek M, Erdman R, Hartman C, Yeager S, Blosky MA, Krum W, Carey DJ, Skelding KA, Benotti P, Stewart WF, Gerhard GS: Association of chromosome 9p21 SNPs with cardiovascular phenotypes in morbid obesity using electronic health record data. Genomic Med 2008, 2:33-43.

18. Juo SH: Genetics of carotid atherosclerosis. Front Biosci 2009, 14:4525-4534.

19. Schunkert H, Gotz A, Braund P, McGinnis R, Tregouet DA, Mangino M, Linsel-Nitschke P, Cambien F, Hengstenberg C, Stark K, Blankenberg S, Tiret L, Ducimetiere P, Keniry A, Ghori MJ, Schreiber S, El Mokhtari NE Hall AS, Dixon RJ, Goodall AH, Liptau H, Pollard H, Schwarz DF, Hothorn LA, Wichmann HE, Konig IR, Fischer M, Meisinger C, Ouwehand W, Deloukas P, Thompson JR, Erdmann J, Ziegler A, Samani NJ: Repeated replication and a prospective meta-analysis of the association between chromosome 9p21.3 and coronary artery disease. Circulation 2008, 117:1675-1684.

20. Signorelli SS, Barresi V, Musso N, Anzaldi M, Croce E, Fiore V, Condorelli DF: Polymorphisms of steroid 5-alpha-reductase type I (SRD5A1) gene are associated to peripheral arterial disease. J Endocrinol Invest 2008, 31:1092-1097.

21. Thorgeirsson TE, Geller F, Sulem P, Rafnar T, Wiste A, Magnusson KP Manolescu A, Thorleifsson G, Stefansson H, Ingason A, Stacey SN, Bergthorsson JT, Thorlacius S, Gudmundsson J, Jonsson T, Jakobsdottir M, Saemundsdottir J, Olafsdottir O, Gudmundsson L, Bjornsdottir G, Kristjansson K, Skuladottir H, Isaksson HJ, Gudbjartsson T, Jones GT, Mueller T, Gottsater A, Flex A, Aben KK, de Vegt F, Mulders PF, Isla D, Vidal MJ, Asin L, Saez B, Murillo L, Blondal T, Kolbeinsson H, Stefansson JG, Hansdottir I, Runarsdottir V, Pola R, Lindblad B, van Rij AM, Dieplinger B, Haltmayer M, Mayordomo Jl, Kiemeney LA, Matthiasson SE, Oskarsson H, Tyrfingsson T, Gudbjartsson DF, Gulcher JR, Jonsson S, Thorsteinsdottir U, Kong A, Stefansson K: A variant associated with nicotine dependence, lung cancer and peripheral arterial disease. Nature 2008, 452:638-642.

22. Gschwendtner A, Bevan S, Cole JW, Plourde A, Matarin M, Ross-Adams H, Meitinger T, Wichmann E, Mitchell BD, Furie K, Slowik A, Rich SS, Syme PD, MacLeod MJ, Meschia JF, Rosand J, Kittner SJ, Markus HS, Muller-Myhsok B, Dichgans M: Sequence variants on chromosome 9p21.3 confer risk for atherosclerotic stroke. Ann Neurol 2009, 65:531-539.

23. Lemmens R, Abboud S, Robberecht W, Vanhees L, Pandolfo M, Thijs V, Goris A: Variant on 9p21 strongly associates with coronary heart disease, but lacks association with common stroke. Eur J Hum Genet 2009, 17:1287-1293
24. Nyquist PA, Winkler CA, McKenzie LM, Yanek LR, Becker LC, Becker DM: Single nucleotide polymorphisms in monocyte chemoattractant protein1 and its receptor act synergistically to increase the risk of carotid atherosclerosis. Cerebrovasc Dis 2009, 28:124-130.

\section{Pre-publication history}

The pre-publication history for this paper can be accessed here: http://www.biomedcentral.com/1471-2261/10/46/prepub

doi:10.1186/1471-2261-10-46

Cite this article as: Skelding et al: Association of an INSIG2 obesity allele with cardiovascular phenotypes is gender and age dependent. $B M C$ Cardiovascular Disorders 2010 10:46.

\section{Submit your next manuscript to BioMed Central and take full advantage of:}

- Convenient online submission

- Thorough peer review

- No space constraints or color figure charges

- Immediate publication on acceptance

- Inclusion in PubMed, CAS, Scopus and Google Scholar

- Research which is freely available for redistribution

Submit your manuscript at www.biomedcentral.com/submit
C) Biomed Central 